\title{
Perbandingan Kemampuan Menulis Permulaan Siswa Kelas 1 SD Negeri 004 Batu Ampar Berdasarkan Siswa Tamatan TK dan Tidak Tamatan TK
}

\author{
Deantika Prawita Putri ${ }^{1}$, Otang Kurniaman ${ }^{2}$, Neni Hermita ${ }^{3}$ \\ 1,2,3 Prgram Studi Pendidikan Guru Sekolah Dasar, FKIP Universitas Riau \\ e-mail: neni.hermita@lecturer.unri.ac.id
}

\begin{abstract}
This research is intended to describe the starting skiills of students class 1 SD Negeri 004 of Batu Ampar, based on kindergarten students and nonkindergarten students. The subject of this was 20 students class 1 SD Negeri 004 of Batu Ampar stone made up of 10 students who graduated from kindergarten and 10 those students who didn't graduate from kindergarten. The method employed in the study is a quatitative descriptive method and dating-collection instrument consisting of tests consisting of 20 short written tests, which divide into four types of the vait: thicking letters, thicking words, copying words and copying sentences. The data obtained is further analyzed using a descriptive statistical technique. Studies suggest that there is a differenc betwen the ability to write an undergraduate students. In wich one woul have been a hundred times better writing ability for kindergarten students than avarage grades for kindergarten students $86,1 \%$ in "very good" and students didn't kindergarten are $74,2 \%$ in category "good".
\end{abstract}

Keywords: ability, prescribing

\section{PENDAHULUAN}

Pendidikan pada sekolah dasar merupakan pondasi awal yang sangat penting. Yakni sebagai bekal peserta didik untuk melangkah pada jenjang selanjutnya. Pendidikan berperan penting dalam mencerdaskan anak bangsa yang mempunyai nilai, norma, harkat dan martabat yang tinggi. Adanya pendidikan diharapkan dapat tumbuh dan berkembangnya potensi, bakat dan kepribadian yang baik dalam diri seseorang. Sehingga tujuan dari pendidikan itu dapat tercapai sebagaimana yang telah diharapkan. Tujuan dari pendidikan itu sendiri adalah untuk mencerdaskan anak bangsa, sebagaimana yang telah dicantumkan dalam UUD 1945 yaitu mencerdaskan kehidupan bangsa. Didalam suatu pendidikan disokong oleh beberapa mata pelajaran salah satunya yaitu bahasa Indonesia.

Bahasa Indonesia adalah mata pelajaran yang memegang peranan penting dalam dunia pendidikan. Karena bahasa Indonesia adalah bahasa resmi yakni sebagai bahasa pengantar di dunia pendidikan. Selain itu, bahasa Indonesia juga sebagai salah satu mata El-Ibtidaiy: Journal of Primary Education, Vol. 4, No. 1, April 2021, Hal 17-29 
pelajaran wajib pada setiap jenjang pendidikan dan merupakan penunjang dalam semua bidang studi. Adanya mata pelajaran ini bertujuan untuk meningkatkan kemampuan peserta didik untuk berkomunikasi dalam bahasa Indonesia dengan baik dan benar, baik secara lisan maupun tulisan serta menumbuhkan apresiasi terhadap hasil karya kesastraan masyarakat Indonesia.Standar kompetensi pada kurikulum 2013 mata pelajaran bahasa Indonesia sebagai acuan kemampuan minimal peserta didik yang menggambarkan penguasaan pengetahuan, keterampilan berbahasa, dan sikap positif kepada bahasa Indonesia. Hal ini menjadi dasar bagi peserta didik untuk memahami, merespon situasi lokal, nasional maupun global. Pada pembelajaran bahasa Indonesia, ditanamkan empat keterampilan berbahasa keterampilan tersebut ialah keterampilan menyimak, berbicara, membaca dan menulis. Keempat keterampilan ini memiliki hubungan yang merupakan satu kesatuan yang tidak bisa dipisahkan satu dengan yang lainnya.

Empat keterampilan dalam bahasa ini penting, namun yang paling penting adalah keterampilan menulis, karena menulis merupakan aktifitas yang berbeda dibandingkan dengan kemampuan berbicara maupun yang lainnya. Dalam menulis dibutuhkan kesabaran, keuletan, dan kejelian tersendiri. Menulis merupakan suatu kegiatan membuat lambang atau grafik baik huruf maupun angka yang maknanya mudah dipahami oleh pembaca dan merupakan suatu bahasa yang dipahami oleh pengguna bahasa (Tarigan 2008:22). Menulis adalah menurunkan atau melukiskan lambang-lambang grafis yang menggambarkan suatu bahasa yang dipahami oleh orang lain, sehingga orang tersebut dapat membaca lambang-lambang grafis tersebut (Djago Tarigan dalam Haryadi dan hamzah, 2012:77).

Pada kelas rendah I dan II menulis disebut menulis permulaan, menulis permulaan merupakan kegiatan menulis yang mengorientasikan pada kemampuan yang bersifat mekanik, peserta didik dilatih untuk dapat menuliskan mirip dengan (melukis atau menggambar) lambang-lambang tulis yang jika dirangkai menjadi bermakna dan dapat dipahami oleh pembaca (Yeti Mulyati dalam Wahni Hidayah, 2016:1). Menulis permulaan adalah tahap awal menguasai kemampuan menulis lanjut dan suatu prasyarat untuk belajar pada tahap selanjutnya (Mumpuniarti dalam Destiani 2016:19). Sebelum seorang anak menguasai kemampuan menulis dengan baik diperlukan adanya prasyarat dalam menulis yang harus dikuasai yaitu kemampuan menulis permulaan yang mencakup penulisan huruf-huruf secara benar dan selanjutnya dia mampu menulis kata-kata bahkan kalimat melalui buku atau tulisan di papan tulis.

Berdasarkan hasil observasi awal, yang dilakukan peneliti di lapangan yaitu kelas 1 SD Negeri 004 Batu Ampar yaitu pada bulan Desember 2019. Pada proses pembelajaran menulis permulaan peneliti menemukan permasalahan mengenai kemampuan menulis siswa. Yakni terdapat perbedaan kemampuan menulis permulaan siswa. Disaat berlangsungnya proses pembelajaran ada beberapa siswa yang belum dapat menulis kata dengan benar contohnya kata bunga menjadi buga, banyak menjadi bayak, harimau menjadi harmau dan lain-lain. Informasi dari guru penyebabnya adalah pendidikan sebelumnya dari siswa tamatan TK atau tidak tamatan TK. Berdasarkan uraian di atas, 
maka peneliti tertarik melakukan penelitian terkait kemampuan menulis permulaan. Nantinya peneliti mengkaji perbedaan kemampuan menulis permulaan antara peserta didik yang tamatan TK dan tidak tamatan TK. Penelitian ini menggunakan metode kuantitatif yang berjudul "Perbandingan Kemampuan Menulis Permulaan Siswa Kelas 1 SD Negeri 004 Batu Ampar berdasarkan siswa tamatan TK dan tidak tamatan TK”.

\section{METODOLOGI}

Jenis penelitian pada penelitian ini adalah deskriptif kuantitatif, dengan sumber data yang diambil dari wali kelas 1 dan siswa kelas 1 SD Negeri 004 Batu Ampar. Data yang diperoleh oleh peneliti melalui tes tertulis, dokumentasi dan observasi. Pada penelitian ini peneliti menggunakan metode kuantitatif.

Penelitian kuantitatif adalah suatu proses menemukan pengetahuan yang mengunakan data berupa angka sebagai alat menemukan keterangan mengenai apa yang akan diketahui oleh peneliti Menurut Margono (2010:105). Deskriptif merupakan analisis yang menggambarkan suatu data yang akan dibuat baik sendiri maupun kelompok bertujuan untuk membuat gambaran secara sistematis data yang faktual dan akurat mengenai fakta-fakta serta hubungan antar fenomena yang diselidiki atau diteliti (Alim, dkk 2009:20).

Subjek penelitian pada penelitian ini adalah siswa kelas 1 SD Negeri 004 Batu Ampar. Jumlah keseluruhan siswa kelas 1 adalah 36 orang siswa. Berikut tabel penjelasannya:

Tabel 1 Jumlah Siswa kelas 1 SD Negeri 004 Batu Ampar

\begin{tabular}{rrrrrr}
\hline \multicolumn{3}{c}{ Kelas 1A } & \multicolumn{3}{c}{ Kelas 1 B } \\
\hline Laki-laki & $: 8$ & Tamatan TK: 5 & Laki-laki $: 9$ & Tamatan TK : 11 \\
Perempuan & $: 10$ & Tidak TK & $: 13$ & Perempuan : 9 & Tidak TK $\quad: 7$ \\
\multicolumn{2}{c}{ Jumlah siswa: 18 siswa } & & Jumlah siswa: 18 siswa
\end{tabular}

Jumlah keseluruhan siswa kelas 1 A dan 1 B : 36 orang siswa

Peneliti mendapatkan data berdasarkan observasi, dokumentasi, dan tes tertulis. Hal ini dilakukan untuk mengetahui kemampuan menulis permulaan siswa kelas 1 SD Negeri 004 Batu Ampar. Instrumen yang digunakan pada penelitian ini adalah tes tertulis berbentuk isian singkat yang berjumlah 20 buah soal. Adapun hasil belajar yang diharapkan dan indikator untuk tes tertulis adalah sebagai berikut: 
Tabel 2 Hasil belajar yang diharapkan dan Indikator

\begin{tabular}{ll}
\hline \multicolumn{1}{c}{ Hasil belajar yang diharapkan } & \multicolumn{1}{c}{ Indikator } \\
\hline Mampu Menulis/menyalin ungkapan & Menulis/menyalin ungkapan \\
pemberitahuan & pemberitahuan \\
Mampu Menulis/menyalin ungkapan & Menulis/menyalin ungkapan maaf \\
maaf & Menulis/menyalin ungkapan tolong \\
Mampu Menulis/menyalin ungkapan & Menulis/menyalin ungkapan \\
tolong & terimakasih \\
Mampu Menulis/menyalin ungkapan & \\
terimakasih & \\
\hline
\end{tabular}

\section{Teknik Pengumpulan Data}

Langkah yang paling utama dalam penelitian adalah teknik pengumpulan data, sebab tujuan utama dari suatu penelitian adalah mendapatkan data. Tanpa mengetahui teknik pengumpulan data yang jelas dipastikan peneliti tidak akan mendapatkan data yang memenuhi standar data yang ditetapkan. Adapun teknik pengumpulan data pada penelitian ini yaitu observasi, dokumentasi dan tes tertulis. Peneliti membagikan tes tertulis kepada siswa kelas 1 SD Negeri 004 Batu Ampar, tes tertulis ini berbentuk soal isian singkat. Dari hasil tertulis tersebut peneliti mendapatkan jawaban mengenai kemampuan menulis permulaan siswa kelas 1 SD Negeri 004 Batu Ampar.

Tabel 3 Kisi-Kisi Tes Kemampuan Menulis Permulaan

\begin{tabular}{|c|c|c|c|}
\hline Kompetensi Dasar & Indikator & Butir Soal & $\begin{array}{l}\text { Jumlah } \\
\text { soal }\end{array}$ \\
\hline $\begin{array}{l}\text { Mempraktikkan ungkapan } \\
\text { penyampaian terima kasih, }\end{array}$ & $\begin{array}{l}\text { Menulis/menyalin ungkapan } \\
\text { pemberitahuan }\end{array}$ & $1,2,3,4,5$ & 5 \\
\hline $\begin{array}{l}\text { permintaan maaf, tolong, dan } \\
\text { pemberian pujian, ajakan, } \\
\text { pemberitahuan, perintah, dan }\end{array}$ & $\begin{array}{l}\text { Menulis/menyalin ungkapan } \\
\text { maaf }\end{array}$ & $6,7,8,9,10$ & 5 \\
\hline $\begin{array}{l}\text { petunjuk } \\
\text { kepada orang lain dengan } \\
\text { menggunakan bahasa yang }\end{array}$ & $\begin{array}{l}\text { Menulis/menyalin ungkapan } \\
\text { tolong }\end{array}$ & $11,12,13,14,15$ & 5 \\
\hline $\begin{array}{l}\text { santun secara lisan dan } \\
\text { tulisan yang dapat dibantu } \\
\text { dengan kosa kata bahasa daerah. }\end{array}$ & $\begin{array}{l}\text { Menulis/menyalin ungkapan } \\
\text { terimakasih }\end{array}$ & $16,17,18,19,20$ & 5 \\
\hline Jumlah & & 20 & 20 \\
\hline
\end{tabular}

Adapun langkah-langkah dalam membuat tes untuk kerja kemampuan menulis permulaan berdasarkan atau berpatokan pada Silabus (Kelas 1, Tema 6 "Lingkungan Bersih Sehat Dan Asri", Sub Tema 4 "Berkerjasama Menjaga Kebersihan dan Kesehatan El-Ibtidaiy: Journal of Primary Education, Vol. 4, No. 1, April 2021, Hal 17-29 
Lingkungan", Pembelajaran ke 1). Adapun Langkah-langkah dalam membuat instrument tes tertulis pada penelitian meliputi (1) menentukan silabus, (2) menentukan kompetensi dasar (KD), (3) menentukan indikator, (4) Menentukan butir tes atau soal, (5) Membuat kisi-kisi tes

Kisi-kisi yang digunakan dalam instrumen tes tertulis dalam pelaksanaan kemampuan menulis permulaan di SD Negeri 004 Batu Ampar ialah sebagai berikut:

\section{Teknik Analisis Data}

Analisis data pada penelitian kuantitatif dilakukan pada saat pengumpulan data berlangsung, dan juga setelah selesai pengumpulan data dalam periode tertentu. Rancangan analisis data merupakan proses penelitian yang dituangkan baik dalam bentuk tulisan atau tidak. Rancangan ini terformat sebelum kegiatan pengumpulan data dan pada saat merumuskan hipotesis. Artinya, rancangan analisis data hasil penelitian telah dipersiapkan mulai dari penentuan jenis data yang akan dikumpulkan, sumber data yang akan ditemui, dan rumusan hipotesis yang akan di uji telah dibuat. Analisis data pada penelitian ini bersifat kuantitatif atau statistik, pada penelitian kuantitatif kegiatan analisis data meliputi pengolahan data dan penyajian data, menggunakan perhitungan untuk mendeskripsikan data dan melakukan pengujian hipotesis dengan menggunakan uji statistik.

\section{Skoring}

Skoring bertujuan untuk mendapatkan gambaran terhadap pemberian instrumen tes tertulis yang di isi oleh siswa kelas 1 SD Negeri 004 Batu Ampar. Menurut peneliti teknik skoring atau pemberian skor bisa diartikan sebagai pemberian nilai yang berbentuk angka terhadap apa yang dikerjakan oleh siswa. Adapun langkah-langkah yang dilaksanakan untuk memberikan skor pada tes tertulis yang di isi siswa adalah sebagai berikut:

(1)Menentukan rentang skor (skor minimal 20 - skor maksimal 100)

Jika siswa mendapatkan skor terendah yaitu 1 pada setiap soal dan setelah itu di jumlahkan maka hasilnya tersebut adalah skor terendah. Dan jika siswa mendapatkan skor tertinggi yaitu 5 pada setiap soal dan setelah itu di jumlahkan maka hasilnya tersebut adalah skor tertinggi. (2) Menentukan jumlah kategori, yakni sangat baik, baik, cukup, kurang dan sangat kurang. Berikut tabel penjelasannya:

Interval skor atau rentang nilai Ini berdasarkan nilai yang ditetapkan pada tabel diatas (kategori tes kemampuan menulis permulaan) yaitu rentang interval atau rentang skornya 20. Mendapatkan keseluruhan nilai siswa dengan menggunakan rumus menurut Supryadi (dalam Yuyun Pertiwi, 2018:104) yakni sebagai berikut:

Keterangan :

$$
\mathrm{P}=\frac{\sum F x}{n} x 100
$$

$\mathrm{P} \quad$ : Tingkat Kemampuan

$\sum F_{x} \quad$ : Jumlah skor yang diperoleh

$\mathrm{n} \quad$ : Jumlah skor maksimal 
Tabel 4 Kategori Tes Kemampuan Menulis Permulaan

\begin{tabular}{ccr}
\hline Skor/ nilai siswa & Kategori & Skor \\
\hline$>80$ & Sangat Baik & 5 \\
$>60-80$ & Baik & 4 \\
$>40-60$ & Cukup & 3 \\
$>20-40$ & Kurang & 2 \\
$<20$ & Sangat Kurang & 1 \\
\hline
\end{tabular}

\section{HASIL DAN PEMBAHASAN}

\section{Hasil Penelitian}

Pengambilan data pada penelitian ini yakni pada kelas 1 SD Negeri 004 Batu Ampar dengan membagikan instrumen tes tertulis kepada siswa. Adapun waktu penelitian atau pengumpulan data dilaksanakan pada 30 April- 03 mei 2020. Adapun langkah-langkah pengumpulan data dalam penelitian ini adalah sebagai berikut: (1)Mengkonfirmasi kepada kepala sekolah SD Negeri 004 Batu A mpar dan kepala desa Batu Ampar bahwa akan melaksanakan penelitian di SD Negeri 004 Batu Ampar. (2) Mendapatkan data siswa dengan mendatangi atau meminta langsung kepada wali kelas 1 SD Negeri 004 Batu Ampar. (3) Peneliti menentukan subjek penelitian berdasarkan data siswa atau nama-nama siswa yang di dapatkan dari wali kelas 1 SD Negeri 004 Batu Ampar. (4) Setelah itu peneliti menentukan subjek penelitian, Dengan membagi siswa menjadi 10 siswa tamatan TK dan 10 siswa yang tidak tamatan TK. (5) Mendatangi siswa (subjek) penelitian ke rumah masing-masing. (6) Peneliti menyediakan alat tulis (Pensil, Penghapus, peruncing pensil dan lembar tes tertulis) (7) Peneliti menjelaskan cara mengerjakan instrumen tes tertulis kepada siswa. (8) Setiap siswa membutuhkan waktu 15-20 menit dalam mengerjakan tes tertulis. (9) Mengambil dokumentasi.

Perbandingan Hasil Penilaian Pada Jenis Soal "Menulis/menyalin ungkapan pemberitahuan"

Pada jenis soal "Menulis/menyalin ungkapan pemberitahuan" ini, siswa diminta untuk menebalkan trace kalimat ungkapan pemberitahuan yang telah disediakan di dalam soal. Trace kalimat ungkapan pemberitahuan ini merupakan kumpulan titik-titik yang saling terhubung membentuk sebuah pola yang berbentuk gabungan huruf, yang menjadi kalimat ungkapan pemberitahuan. Dalam jenis soal ini, terdapat 5 (lima) butir soal. Lima (5) butir soal tersebut terdiri dari menebalkan kalimat ungkapan pemberitahuan sebagai berikut:Rahma membantu Ibu membersihkan rumah, Ratna menyiram tanaman di kebun, Nisa sedang mengerjakan PR, Rani membawa bekal ke sekolah, Andi sedang bermain bola. Siswa akan diminta untuk menghubungkan titik-titik yang telah disediakan sehingga membentuk gabungan huruf-huruf yang menjadi kalimat ungkapan pemberitahuan. Hasil penelitian terhadap 10 anak yang tamatan TK dan 10 anak yang tidak tamatan TK dapat dilihat pada tabel di bawah ini : 


\section{Tabel 5 Hasil penilaian pada jenis soal "Menulis/menyalin ungkapan pemberitahuan.}

\begin{tabular}{lll}
\hline \multirow{2}{*}{ Jenis Soal } & \multicolumn{2}{l}{ Hasil Penelitian } \\
\cline { 2 - 3 } & Siswa yang tamatan TK & $\begin{array}{l}\text { Siswa yang bukan } \\
\text { tamatan TK }\end{array}$ \\
\hline $\begin{array}{l}\text { Menulis/menyalin } \\
\text { ungkapan pemberitahuan. }\end{array}$ & $76,4 \%$ & $77,6 \%$
\end{tabular}

Berdasarkan tabel 5 di atas dapat dilihat nilai rata-rata siswa yang tamatan TK dan siswa yang tidak tamatan TK dalam menjawab soal, dengan jenis soal "menulis/menyalin ungkapan pemberitahuan". Hasil penelitian menunjukkan bahwa nilai rata-rata siswa yang tamatan TK adalah 76,4\% dengan kategori "Baik" dan siswa yang tidak TK adalah 77,6\% dengan kategori "Baik". Ini menunjukkan bahwa siswa yang tidak tamatan TK memiliki nilai yang lebih tinggi dibanding siswa yang tamatan TK dalam hal menulis atau menebalkan kalimat ungkapan pemberitahuan. dengan selisih nilai di antara keduanya adalah 1,2 .

Perbandingan Hasil Penelitian Pada Jenis Soal “Menulis/menyalin ungkapan maaf'.

Pada jenis soal "menulis/menyalin ungkapan maaf" ini, siswa diminta untuk menulis/menyalin kalimat ungkapan maaf. Dalam jenis soal ini, terdapat 5 (lima) butir soal. 5 (lima) butir soal tersebut adalah kalimat ungkapan maaf yakni sebagai berikut: Bu Guru, maaf saya terlambat datang ke sekolah, Maaf Rara, saya tidak sengaja menjatuhkan buku kamu, Bu Guru, maaf seragam olah raga saya ketinggalan, Kakak, maaf saya telah menghabiskan makanannya, Udin, maaf saya tidak sengaja menghilangkan mainan kamu. Siswa akan diminta untuk menulis/menyalin kalimat ungkapan maaf diatas. Hasil penelitian terhadap 10 anak yang tamat TK dan 10 anak yang tidak TK dapat dilihat pada tabel di bawah ini :

Tabel 6 Hasil penilaian pada jenis soal "Menulis/menyalin ungkapan maaf

\begin{tabular}{lcc}
\hline \multirow{2}{*}{ Jenis Soal } & \multicolumn{2}{c}{ Hasil Penelitian } \\
\cline { 2 - 3 } & Siswa yang tamatan TK & $\begin{array}{c}\text { Siswa yang bukan } \\
\text { tamatan TK }\end{array}$ \\
\hline $\begin{array}{l}\text { Menulis/menyalin } \\
\text { ungkapan maaf }\end{array}$ & $93,6 \%$ & $76 \%$ \\
\hline
\end{tabular}

Berdasarkan tabel 6 di atas dapat dilihat nilai rata-rata siswa yang tamatan TK dan siswa yang tidak tamatan TK dalam menjawab soal dengan jenis soal "menulis/menyalin ungkapan maaf'. Hasil penelitian menunjukkan bahwa nilai rata-rata siswa yang tamat TK adalah 93,6\% dengan kategori "Sangat Baik" dan siswa yang tidak TK adalah 76\% dengan kategori "Baik". Ini menunjukkan bahwa siswa yang tamatan TK memiliki nilai yang lebih tinggi dibanding siswa yang tidak tamatan TK dalam hal menulis/menyalin kalimat ungkapan maaf. dengan selisih nilai di antara keduanya adalah 17.6.

El-Ibtidaiy: Journal of Primary Education, Vol. 4, No. 1, April 2021, Hal 17-29 

tolong"

Perbandingan Hasil Penelitian Pada Jenis Soal "Menulis/menyalin ungkapan

Pada jenis soal "menulis/menyalin ungkapan tolong" ini, siswa diminta untuk menyalin kalimat ungkapan tolong yang telah disediakan di dalam soal. Dalam jenis soal ini, terdapat 5 (lima) butir soal. 5 (lima) butir soal tersebut yakni kalimat ungkapan tolong sebagai berikut: Ibnu bolehkah saya minta tolong, ambilkan baju saya di tas. Kakak, tolong ajari saya mengerjakan PR, Ibu, tolong buatkan saya telor dadar kesukaan saya, Ayah, tolong perbaiki mainan saya yang rusak. Bu Guru, tolong jelaskan Kembali saya tidak mengerti.

Hasil penelitian terhadap 10 anak yang tamatan TK dan 10 anak yang tidak tamatan TK dapat dilihat pada tabel di bawah ini :

Tabel 7 Hasil penilaian pada jenis soal "Menulis/menyalin ungkapan tolong

\begin{tabular}{lcc}
\hline \multirow{2}{*}{ Jenis Soal } & \multicolumn{2}{c}{ Hasil Penelitian } \\
\cline { 2 - 3 } & Siswa yang Tamat TK & $\begin{array}{c}\text { Siswa yang tidak } \\
\text { TK }\end{array}$ \\
\hline $\begin{array}{l}\text { Menulis/menyalin } \\
\text { ungkapan tolong }\end{array}$ & $90,8 \%$ & $74,4 \%$ \\
\hline
\end{tabular}

Berdasarkan tabel $7 \mathrm{di}$ atas dapat dilihat nilai rata-rata siswa yang tamatan TK dan siswa yang tidak tamatan TK dalam menjawab soal dengan jenis soal "menulis/menyalin ungkapan tolong". Hasil penelitian menunjukkan bahwa nilai rata-rata siswa yang tamatan TK adalah 90,8\% dengan kategori "Sangat Baik" dan siswa yang tidak tamatan TK adalah $74,4 \%$ dengan kategori "Baik". dalam hal menulis/menyalin kalimat ungkapan tolong dengan selisih nilai di antara keduanya adalah 16,4. kasih"

Perbandingan Hasil Penelitian Pada Jenis Soal "Menulis/menyalin ungkapan terima

Pada jenis soal "Menulis / menyalin ungkapan terima kasih" ini, siswa diminta untuk menulis menyalin kembali kalimat ungkapan terima kasih yang telah disediakan di dalam soal. Dalam jenis soal ini, terdapat 5 (lima) butir soal. 5 (lima) butir soal tersebut adalah kalimat ungkapan terima kasih sebagai berikut: Ayah, terima kasih sudah menjemput saya pulang sekolah, Ibu, terima kasih sudah membelikan saya makanan, Ayah, terima kasih sudah membelikan saya mainan baru, Kakak, terima kasih sudah mengajari saya mengerjakan PR, Terimakasih Ibu, telah memasak enak hari ini. Hasil penelitian terhadap 10 anak yang tamat TK dan 10 anak yang tidak TK dapat dilihat pada tabel di bawah ini.

Berdasarkan tabel 8 di atas dapat dilihat nilai rata-rata siswa yang tamatan TK dan siswa yang tidak tamatan TK dalam menjawab soal dengan jenis soal "Menulis/menyalin ungkapan terima kasih". Hasil penelitian menunjukkan bahwa nilai rata-rata siswa yang tamatan TK adalah 83,6\% dengan kategori "Sangat Baik" dan siswa yang tidak tamatan TK adalah 68,8\% dengan kategori "Baik". dalam hal menulis/menyalin kalimat ungkapan terima kasih dengan selisih nilai di antara keduanya adalah 14,8 . 
Tabel 8 Hasil penilaian pada jenis soal "Menulis/menyalin ungkapan terima kasih

\begin{tabular}{ccc}
\hline \multirow{2}{*}{ Jenis Soal } & Siswa yang Tamat TK & $\begin{array}{c}\text { Siswa yang } \\
\text { tidak TK }\end{array}$ \\
\cline { 2 - 3 } $\begin{array}{c}\text { Menulis/menyalin } \\
\text { ungkapan terima kasih }\end{array}$ & $83,6 \%$ & $68,8 \%$ \\
\hline
\end{tabular}

\section{Perbandingan Nilai Akhir}

Perbandingan ini diambil dengan cara mencari rata-rata dari nilai-nilai yang diperoleh siswa. Tujuannya untuk mengetahui nilai akhir yang akan memberikan kesimpulan mengenai kemampan menulis permulaan siswa kelas 1 SD Negeri 004 Batu Ampar, yaitu antara siswa yang tamatan TK dan yang bukan tamatan TK. Nilai akhir yang diperoleh dapat dilihat pada tabel di bawah ini:

Tabel 9 Nilai akhir yang didapat siswa

\begin{tabular}{ccc}
\hline \multirow{2}{*}{ Jenis Nilai } & \multicolumn{2}{c}{ Hasil Penelitian } \\
\cline { 2 - 3 } & Siswa yang Tamat TK & $\begin{array}{c}\text { Siswa yang } \\
\text { tidak TK }\end{array}$ \\
\hline Nilai Akhir & $86,1 \%$ & $74,2 \%$ \\
\hline
\end{tabular}

Berdasarkan tabel 9 di atas dapat dilihat nilai akhir yang berasal dari nilai rata-rata semua jenis soal yang diberikan. Hasil penelitian menunjukkan bahwa nilai akhir siswa yang tamatan TK adalah 86,1\% dengan kategori "Sangat Baik" dan siswa yang tidak TK adalah $74,2 \%$ dengan kategori "Baik" dengan selisih nilai di antara keduanya adalah 11,9 . Ini menunjukkan bahwa siswa yang tamatan TK memiliki kemampuan menulis permulaan lebih baik dibanding siswa yang tidak tamatan TK. Secara rinci hasil penelitian ini dapat dilihat pada lampiran 8 dan 9 .

\section{Pembahasan}

Berdasarkan hasil penelitian terhadap kemampuan menulis permulaan siswa kelas 1 SD Negeri 004 Batu Ampar yang tamatan TK dan tidak tamatan TK, maka perbandingan keduanya dikatakan berbeda antara kemampuan antara siswa tamatan TK dan tidak tamatan TK. Siswa yang tamatan TK memiliki skor yang lebih tinggi dibandingkan siswa yang tidak tamatan TK, Walaupun skor keduanya tidak jauh berbeda namun dari tingkat kerapian tulisan jelas berbeda antara siswa tamatan TK dan tidak. Hasil tulisan siswa yang tamatan TK pada tes tertulis terlihat lebih rapi dibandingkan dengan siswa yang tidak tamatan TK. Siswa yang tidak tamatan TK hasil tulisannya cenderung acak-acakan, tulisan miring, tulisan terlalu rapat, terdapat kekurangan huruf pada kata, huruf kapital terletak ditengan kalimat dan tulisan tidak sesuai dengan tempat yang disediakan.

Pada saat penelitianpun siswa yang tamatan TK lebih serius dan teliti dalam mengerjakan tes tertulis, siswa tamatan TK pun tidak banyak mendapatkan bimbingan saat E1-Ibtidaiy: Journal of Primary Education, Vol. 4, No. 1, April 2021, Hal 17-29 
proses mengerjakan instrumen menulis permulaan. Dikarenakan mereka sudah mengerti apa yang mereka akan lakukan terhadap tes, mereka juga mempunyai rasa kepercayaan tinggi disaat mengerjakan tes. Hal ini berbanding terbalik terhadap siswa yang tidak tamatan TK mereka cenderung malu-malu saat mengerjakan tes tertulis dan terlihat tidak percaya diri disaat pengambilan dokumentasi berupa foto. Disaat proses penelitianpun mereka banyak mendapatkan bimbingan dalam mengerjakan tes tertulis.

\section{Menulis/menyalin ungkapan pemberitahuan}

Pada jenis soal menulis/menyalin ungkapan pemberitahuan ini, siswa diminta untuk menghubungkan titik-titik yang ada di dalam soal menjadi gabungan huruf-huruf yang menjadi kalimat ungkapan pemberitahuan. Tujuannya adalah untuk melihat kemampuan siswa dalam menulis huruf-huruf sesuai dengan kaidah dan bentuknya. Berdasarkan hasil penelitian, siswa yang tamatan TK memiliki nilai rata-rata yang lebih rendah dibandingkan siswa yang bukan tamatan TK. Nilai rata-rata siswa yang tamatan TK adalah $76,4 \%$ dan siswa yang tidak tamatan TK adalah 77,6\%. Artinya, siswa tidak tamatan TK mampu menulis gabungan huruf-huruf menjadi kalimat ungkapan pemberitahuan dengan baik dibanding dengan siswa yang tamatan TK. Walaupun selisih nilai keduanya hanya 1,2. Hanya sedikit sekali selisih perbandingannya.

Pada soal ini siswa yang tidak tamatan TK mempunyai hasil yang rapi, siswa yang tidak tamatan TK cenderung teliti dalam mengerjakan jenis soal ini. Sedangkan siswa yang tamatan TK, menurut pandangan peneliti mereka cenderung cepat dalam mengerjakan jenis soal ini, karena menganggap jenis soal ini mudah sehingga hasilnya kurang rapi jika dibandingkan dengan hasil tulisan siswa yang tidak tamatan TK. walaupun selisih nilai keduanya tidak begitu signifikan atau tidak terlalu jauh selisih hasilnya.

Kemampuan menulis huruf ini sudah dilatih ketika anak duduk dibangku TK. Menurut Hariyani (2016:9), di dalam Kurikulum TK, pembelajaran menulis yang dimaksud bukanlah anak fokus belajar menulis seperti di Sekolah Dasar, tetapi pembelajaran menulis di TK hanya persiapan menulis yang menyangkut kegiatan-kegiatan yang dilakukan oleh motorik halus anak terutama pada bagian 3 jari yaitu ibu jari, telunjuk dan jari tengah. Artinya, anak telah dilatih bagaimana memegang pensil ketika TK sehingga mampu menulis huruf dengan baik.

\section{Menulis/menyalin ungkapan maaf}

Untuk jenis soal menulis/menyalin ungkapan maaf, siswa diajak untuk menyalin kalimat ungkapan maaf yang terdapat di dalam soal. Tujuannya adalah untuk mengetahui kemampuan siswa dalam menulis kumpulan huruf-huruf yang menjadi sebuah kalimat ungkapan maaf tanpa bantuan titik-titik (trace). Cara mengerjakan soal ini yaitu menuliskan Kembali atau menyalin kalimat ungkapan maaf ke tempat yang tersedia pada tes tertulis. Berdasarkan hasil penelitian, siswa yang tamatan TK memiliki nilai rata-rata yang lebih tinggi dibandingkan siswa yang bukan tamatan TK. Nilai rata-rata siswa yang tamatan TK adalah 93,6\% dan siswa yang bukan tamatan TK adalah 76\%. Artinya, siswa tamatan TK 
mampu menulis/menyalin kalimat ungkapan maaf dengan baik dibanding dengan siswa yang bukan tamatan TK.

Peneliti berpendapat bahwa mengapa hasil tulisan siswa yang tamatan TK lebih rapi dan nilainya lebih tinggi dibandingkan siswa yang tidak tamatan TK, dikarenakan siswa tamatan TK lebih terlatih dalam menulis huruf-huruf yang membentuk kata atau kalimat saat mereka melalui jenjang TK dan kemampuan tersebut dikembangkan saat mereka berada di sekolah dasar.

\section{Menulis/menyalin ungkapan tolong}

Pada jenis soal menulis/menyalin ungkapan tolong, siswa diminta untuk menulis kembali atau menyalin kalimat ungkapan tolong yang telah disediakan di dalam soal. Hampir sama caranya dengan soal sebelumnya hanya saja dibedakan dengan jenis ungkapannya. Tujuannya adalah untuk mengetahui kemampuan siswa dalam menulis kalimat ungkapan tolong tanpa bantuan titik-titik (trace). Selain itu, menyalin kalimat ungkapan tolong juga untuk mengetahui apakah siswa mampu menulis dengan urutan huruf yang tepat dan tidak ada yang tertinggal. Berdasarkan hasil penelitian, siswa yang tamatan TK memiliki nilai rata-rata yang lebih tinggi dibandingkan siswa yang tidak tamatan TK. Nilai rata-rata siswa yang tamatan TK adalah 90,8\% dan siswa yang tidak tamatan TK adalah 74,4\%. Artinya, siswa tamatan TK mampu menyalin kalimat ungkapan tolong dengan baik dibanding dengan siswa yang tidak tamatan TK.

Sebuah hasil penelitian yang menarik. Jika dilihat, sebenarnya setiap siswa sudah mampu menulis kata dengan baik. Karena memang sudah dilatih ketika duduk dibangku sekolah dasar (SD). Menurut Jamil dan Irmawati (2017:32) setiap kemampuan menulis yang telah dimiliki oleh anak akan mengalami perkembangan sesuai dengan tahapan perkembangan. Normalnya, semakin bertambah usia maka perkembangan kemampuan menulis anak akan semakin meningkat. Untuk mengembangkan kemampuan dan menumbuhkan keinginan anak menulis, maka orang tua dan guru harus memperhatikan prinsip-prinsip dalam pelaksanaan kegiatan menulis tersebut.

\section{Menulis/menyalin ungkapan terima kasih}

Untuk jenis soal menulis/menyalin ungkapan terima kasih ini, siswa diminta untuk menulis kembali atau menyalin kalimat ungkapan terima kasih yang telah diberikan di dalam soal. Hampir sama caranya dengan soal sebelumnya hanya saja dibedakan dengan jenis ungkapannya. Tujuannya adalah untuk mengetahui kemampuan siswa dalam menulis/menyalin kalimat ungkapan terimakasih tanpa bantuan titik-titik (trace). Selain itu, menyalin kalimat juga untuk mengetahui apakah siswa mampu menulis dengan urutan huruf yang tepat dan tidak ada yang tertinggal. menyalin kalimat ungkapan terima kasih artinya menyalin kumpulan kata menjadi satu kalimat ungkapan terima kasih yang tepat sesuai dengan contohnya.

Berdasarkan hasil penelitian, siswa yang tamatan TK memiliki nilai rata-rata yang lebih tinggi dibandingkan siswa yang bukan tamatan TK. Nilai rata-rata siswa yang tamatan 
TK adalah 83,6\% dan siswa yang bukan tamatan TK adalah 68,8\%. Artinya, siswa tamatan TK mampu menyalin kalimat ungkapan terima kasih dengan baik dibanding dengan siswa yang bukan tamatan TK.

\section{KESIMPULAN}

\section{Simpulan}

Nilai rata-rata dari 4 jenis soal siswa kelas 1 SD Negeri 004 Batu Ampar tamatan TK adalah 86,1\% dengan kategori "Sangat Baik" dan siswa yang tidak tamatan TK adalah 74,2\% dengan kategori "Baik". Jadi Berdasarkan hasil keseluruhan, maka siswa kelas 1 SD Negeri 004 Batu Ampar yang tamatan TK memiliki kemampuan menulis permulaan yang lebih baik dibanding siswa yang tidak tamatan TK. Kesimpulan spesifiknya yakni sebagai berikut: (1) Pada jenis soal "menulis/menyalin ungkapan pemberitahuan", siswa kelas 1 SD Negeri 004 Batu Ampar yang tamatan TK memiliki nilai rata-rata yang lebih rendah dibandingkan siswa yang bukan tamatan TK. Nilai rata-rata siswa yang tamatan TK adalah 76,4\% dengan kategori "Baik" dan siswa yang tidak tamatan TK adalah 77,6\% dengan kategori "Baik". (2) Pada jenis soal "menulis/menyalin ungkapan maaf”, siswa kelas 1 SD Negeri 004 Batu Ampar yang tamatan TK memiliki nilai rata-rata yang lebih tinggi dibandingkan siswa yang tidak tamatan TK. Nilai rata-rata siswa yang tamatan TK adalah 93,6\% dengan kategori "Sangat Baik" dan siswa yang tidak tamatan TK adalah 76\% dengan kategori "Baik". (3) Pada jenis soal "menulis/menyalin ungkapan tolong”, siswa kelas 1 SD Negeri 004 Batu Ampar yang tamatan TK memiliki nilai rata-rata yang lebih tinggi dibandingkan siswa yang tidak tamatan TK. Nilai rata-rata siswa yang tamatan TK adalah 90,8\% dengan kategori "Sangat Baik" dan siswa yang tidak tamatan TK adalah 74,4\% dengan kategori "Baik". (4) Pada jenis soal "menulis/menyalin ungkapan terima kasih", siswa kelas 1 SD Negeri 004 Batu Ampar yang tamatan TK memiliki nilai rata-rata yang lebih tinggi dibandingkan siswa yang bukan tamatan TK. Nilai rata-rata siswa yang tamatan TK adalah 83,6\% dengan kategori "Sangat Baik" dan siswa yang bukan tamatan TK adalah 68,4\% dengan kategori 'Baik'.

\section{Saran}

Bagi Guru: Harus lebih memperhatikan bentuk kesulitan siswa dalam menulis permulaan, dan mempersiapkan strategi pembelajaran yang baik agar kemampuan menulis antara anak yang tamatan TK dan tidak TK menjadi seimbang atau boleh dikatakan tidak adalagi kesenjangan kemampuan menulis diantara keduanya.

\section{REFERENSI}

Alim, Alexsander Jesi, dkk. (2009). Statistik Pendidikan. Pekanbaru: Cendikia Insani.

Arikunto, Suharsini. 1998. Prosedur Penelitian Suatu Pendekatan Praktek. Jakarta: PT Rineka Cipta. 
Destiani, Lusi. (2016). Peningkatan Kemampuan Menulis Permulaan Menggunakan Metode VAKT(Visual Auditori Kenistetik Taktil) Untuk Anak Autis Kelas 1 di SLB Autisme Dian Amanah Yogyakarta (Skripsi). Universitas Negri Yogyakarta:Yogyakarta

Elviyanti, Lenny. (2019). Analisis Faktor Internal Yang Mempengaruhi Motivasi Intrinsik Siswa Kelas V Sd N 147 Pekanbaru Dalam Mengerjakan Pekerjaan Rumah (Pr). (Skripsi). Universitas Riau: Pekanbaru.

Fauziddin, M dan Mufariddin. (2018). Useful of Clap Hand Games For Oplimalize Cogtivite Aspectk in Early Childhood Education. Jurnal Obsesi: Jurnal Pendidikan Anak Usia Dini. Volume 2 Issue 2 (2018) Pages 162-169.

Haryadi dan zamzani. (2012). Peningkatan Keterampilan Berbahasa Indonesia. Jakarta: Departeman Pendidikan Nasional Direktorat Jendral Pendidikan Tinggi.

Margono. (2010). Metodologi Penelitian Pendidikan. Jakarta: Rineka Cipta

Pertiwi, Yuyun. (2018). Analisis Kemampuan Pemenggalan Kata Siswa Kelas III SDN 37 Pekanbaru (Skripsi). Universitas Riau. Pekanbaru

Sugiono. (2018). Metode Penelitian Pendidikan (Pendekatan Kuantitatif dan kualitatif, dan R\&D). Bandung: Alfabeta

Tarigan. (2008). Menulis Sebagai Suatu Keterampilan Berbahasa. Bandung: Angkasa 